\title{
Direct and Indirect Housing Support and Financial Crisis
}

\author{
Yvona Legierska \\ University of Finance and Administration, Prague, Czech Republic
}

\begin{abstract}
The housing supported by the state in the form of subsidies or tax allowances is common in all countries of the European Union. It affects the development of home ownership and standard of living of the population, and promotes residential development associated with construction industry. The objective of this paper is to determine whether the Czech Republic supports housing in manners that pose no risk to financial stability of institutions providing housing loans and whether it helps to modify its tax system in compliance with European Commission recommendations. Its endorsement reacts to the subprime mortgage crisis in the US, which triggered the global economic recession in September 2008. Methods of analysis, synthesis, descriptions of specialized literature and national legislation were used in preparation of the paper.
\end{abstract}

Keywords: mortgage loan, building savings, tax policy, value added tax, financial transaction tax

\section{Introduction}

Governments of many countries provide various types of support to the housing market, predominantly in the form of subsidies and tax allowances. Since the early 1990s, individual governments of the Czech Republic have been establishing conditions aiming at promoting new residential development (construction) as well as promoting real estate market. In the United States support of housing reached such level that it resulted in mortgage crisis on national level, and triggered serious global economic recession in September 2008. Banks, many of which "were rescued" by governments using public funds, significantly contributed to the crisis together with insufficient banking supervision. The European Commission (EC) recommended, among others, modifications of tax systems, including a proposal for introducing new tax on financial transactions, with a view to ensure financial stability in all member states. The objective of the paper is to determine whether the Czech Republic has been supporting its housing since its formation in 1993 in a manner that does not pose risk to the financial stability of institutions providing housing loans and whether it has been modifying its tax system as from 2010 onwards in compliance with recommendations of the EC.

This paper deals with development of housing support in the Czech Republic and analyses its impact or effects in connection with various forms of such support in member states of the European Union (EU).

Important information sources include, but are not limited to, the following: selected materials of the Ministry of Finance (MF), Czech National Bank (CNB), and the International Monetary Fund (IMF). Methods

\footnotetext{
* The paper was prepared as part of Specific University Research No. 7427.

Yvona Legierska, Ph.D. candidate, Department of Finance, University of Finance and Administration, Prague.

Correspondence concerning this article should be addressed to Yvona Legierska, Department of Finance, University of Finance and Administration, Prague, Czech Republic. E-mail: yvona.legierska@seznam.cz.
} 
of analysis, synthesis, and description of specialized literature and national legislation were used in preparing the paper.

\section{Housing Support in the EU and in the Czech Republic}

The state support of housing loans tends to be a rule in member states of the EU. According to the study "Analysis of preconditions for increasing the share of housing development support on the basis of self-financing and refinancing with the use of guarantees" (Klíma, 2010), member states of the EU accentuate direct housing support. In addition to this, indirect housing support exists in the form of tax allowances.

The reason for providing this form of support is not only the development of home ownership, but also dependable residential development associated with construction industry. It translates into development of other sectors, thereby reducing unemployment. This means that the state housing support has a positive multiplier effect associated with gross domestic product growth (GDP); however, the level of such support should be adequate to the potential of given country in respect of its financial stability.

In its 2005 material "On some fiscal effects on mortgage debt growth in the EU", the European Central Bank (ECB) already warned that the household indebtedness had been increasing in countries of the former EU-15 in the past decade, caused by rapid increase in mortgage loans, with significant differences for individual countries. In 2003, the mortgage loan indebtedness ranged from $13 \%$ of GDP (Italy) to $100 \%$ of GDP (The Netherlands). The variability (dispersion) was caused by different support of mortgage loan growth by governments of individual member states (Wolswijk, 2005).

The study of Delloite "The role of the government in EU real estate markets" of April 2010 (Delloite, 2010) characterizes the approach of individual EU member states to the issue of home ownership, particularly from the perspective of tax allowances and risk reduction via the formation of guarantee or security funds. It is clear from the study conclusions that smaller countries and new member states of the EU have less effective measures in place aiming at the housing market support compared to more developed countries with larger economy (France, Germany, Great Britain). The question is whether these "less effective measures" are not a plus during the financial crisis caused by the subprime mortgage crisis in the US, as potential tax distortions are not significant and there are no deformations of the housing market.

Figure 1 shows that the household indebtedness level in relation to GDP in 2011 and 2012 is relatively low in the Czech Republic compared to other EU member states (30.3\% of GDP). The low indebtedness level is also reported by new member states of Central Europe. The most significant year-to-year decline in household indebtedness in 2012 was mainly reported by those economies that experienced growth of indebtedness during the past stages of the economic-financial cycle and it is gradually going down (Great Britain, Denmark, Ireland) or economies (typically the Baltic states) that were successful in reducing the relative indebtedness rate by increasing GDP (MF, 2013a).

Mortgage loans in the Czech Republic were not commonly used for real estate financing until 1996. Only the subsequent banking sector stabilization and state support provided to individuals in the form of tax allowance as of 1998 contributed to more intensive use of this banking product. In 2012, housing loans in the Czech Republic represented 79.2\% of bank loans to households in the Czech Republic. This does not only concern mortgage loans, but also building savings loans. Both products were introduced in the early 1990s in the Czech Republic and have been supported through tax allowance in the form of deduction of interest paid 
from an income tax base; moreover, building savings clients also received contribution from the state budget. However, while the volume of mortgage loans has been constantly increasing, up to CZK 700.5 bn. in 2012, the building savings loans declined for the first time on a year-to-year basis in 2012 , specifically by $3.7 \%$ to CZK $282.2 \mathrm{bn}$., mainly due to the gradually decreasing state contribution (MF, 2013a).

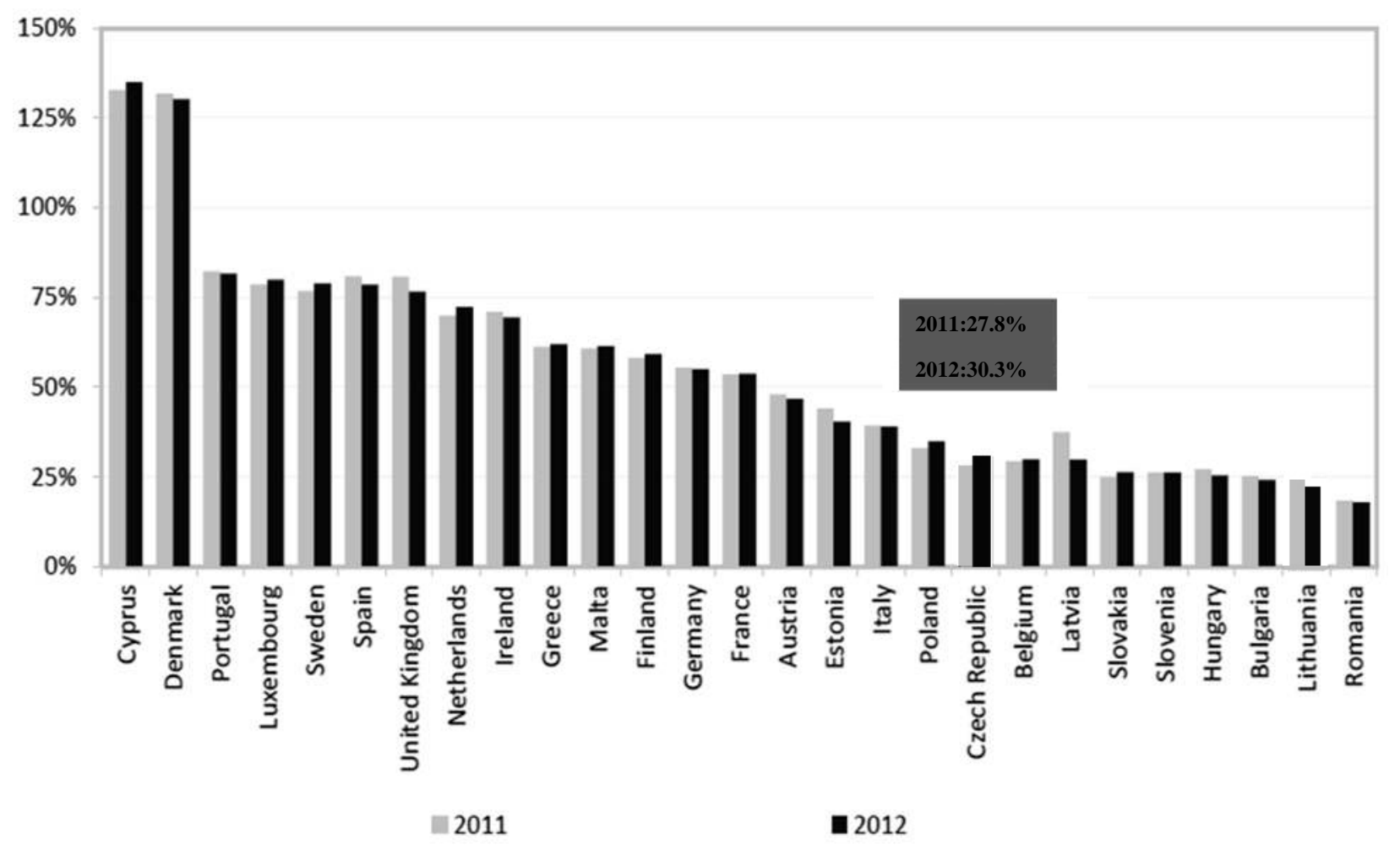

Figure 1. Volume of household indebtedness in the EU in relation to GDP. Source: ECB, Eurostat.

\section{Direct Forms of Housing Support}

The most commonly used forms of direct housing support in individual member states of the EU comprise the following:

- Various investment and noninvestment subsidies that are included directly in the amount of the implemented project (such as the following in the Czech Republic: subsidies were aimed at promoting development of supported apartments, subsidies were aimed at promoting regeneration of panel housing developments/neighborhoods, etc.);

- Various investment and noninvestment subsidies aiming at supporting interest payments on loans drawn for the purpose of implementation the given project (such as the following in the Czech Republic: Program Panel, support of mortgage loans, etc.);

- Preferential loans provided at lower interest rates compared to the average interest rate prevailing on the banking market, or loans provided at the average interest rate; however, for a longer period compared to the customary practice on the free market.

Of the above mentioned direct housing support instruments, the followings were the most important in the Czech Republic in the past decade:

- Support of mortgage loans - both for new development and young people (up to 36 years of age) acquiring older property; 
- Welfare loans for individual and cooperative development and loans to young married couples.

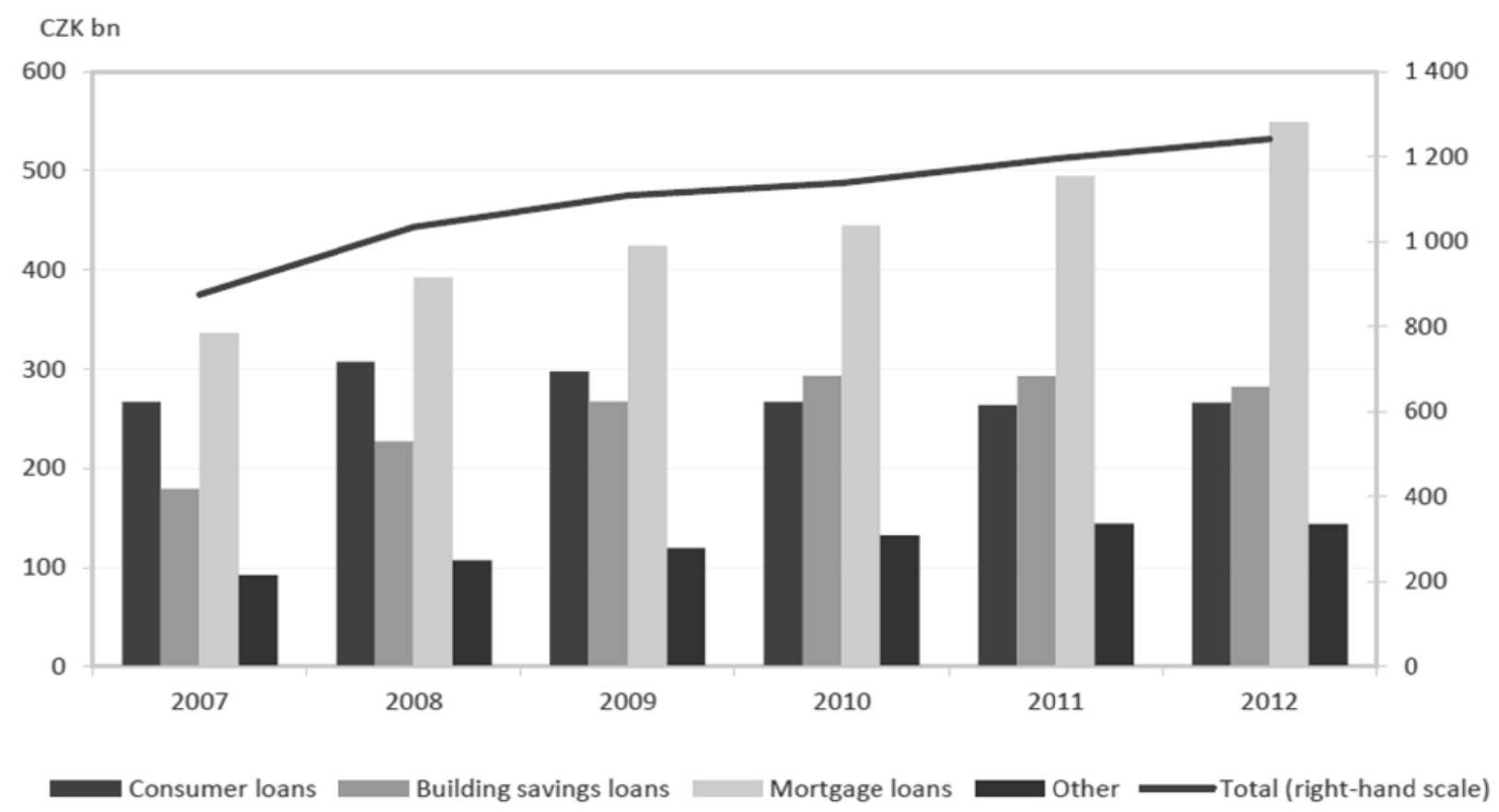

Figure 2. Total household indebtedness. Source: CNB-ARAD.

Considering the significant decrease in the CNB interest rates to the current all-time lows and subsequent reaction of market interest rates, the state mortgage loan support, which culminated in 2003, continues to decline in connection with predetermined parameters and no new applications have basically been accepted since 2004. The welfare loans experienced similar expansion.

\section{Indirect Forms of Housing Support}

The most frequently used forms of indirect housing support in individual member states of the EU comprise the following:

- Possibility to deduct interest paid on loans drawn for acquisition of new housing;

- Possible income tax exemption when residential real estate is sold;

- Value added tax (VAT) exemption for loans;

- Lower VAT rate for new housing development projects;

- Real estate tax exemption.

With regard to possibility to deduct interest paid on loans, this form of support is used in 20 member states of EU; on the other hand, some member states do not provide this tax exemption, or impose VAT on new home ownership projects. This form of deduction is often limited not by an absolute amount, but by a percentage of the amount of interest paid or by a percentage of the taxable income amount (Klíma, 2010).

All the above mentioned forms of housing support were used in the Czech Republic; however, this support has been declining or discontinued in recent years in an attempt at fiscal consolidation of public budgets. The tax support of the Czech mortgage loan market comprises the possibility to deduct the interest paid on mortgage loans/building savings loans from individual income tax base and VAT exemption for the provision of loans. Temporary real-estate tax exemption with regard to property intended for housing represented a 
significant tax relief until 2009.

\section{Financial Crisis, Its Implications in the Czech Republic, and Tax Policy}

The financial crisis was triggered by the U.S. mortgage market problems, immediately resulting from the combination of loose monetary policy of the American Federal Reserve System (FED) as from 2001 and massive state involvement in the mortgage loan market (Hemmelgarn \& Nicodeme, 2010).

Consequently, this promoted the growth of inexpensive company investments and household consumption on credit, particularly in the area of real estate. Moreover, financial innovations of loan/mortgage loan providers started to evolve with a view to ensure sufficient liquidity for other transactions. Therefore, the banks used loans to create the so-called structured financial instruments that were being sold to investors in the form of assets. In this manner, they disposed of the default risk while having a permanent source of necessary liquidity. A relatively complicated mechanism was created for structured derivatives trading not only through specialized companies, but also through investments banks and hedge funds. At the same time, the regulatory and supervision standards of central banks were loosened. The so-called financial leverage was largely used to finance investments under this system. The assumed reduction of risks due to the securitization process stimulated more aggressive investments for the purpose of capital valuations. This is rather crucial in terms of the financial crisis start. The concurrence of all the aforementioned factors caused loosening loan standards. The client solvency checks were becoming less rigorous among loan/mortgage loan providers, even though mortgage loans had the highest share in granted loans (Zemánek, 2008).

In an attempt to prevent surging inflation in the US, the FED started to increase interest rates as from 2004. Mainly lower-income households were no longer able to repay their mortgage loans and, in reaction to this, the FED started to decrease interest rates again during 2007. This resulted in lower real estate prices. First serious problems thus started to become apparent, with subsequent government aid provided to banks. The actual crisis commenced in September 2008, as a series of bankruptcies of investment banks caused panic on the financial markets. All this broke out into a global economic recession (Hemmelgarn \& Nicodeme, 2010).

Trend of increasing interest rates in the Czech Republic (see Figure 3) also started after 2004, i.e., in the period of the highest economic growth (by 7\% in 2005 and 2006) in the history of the country. However, in 2009, the financial crisis also impacted the real economy of the Czech Republic through a contamination channel, as real estate market bubbles originated outside of the Czech Republic, resulting in a year-to-year GDP decline of $4.5 \%$.

The financial leverage in the Czech economy remained relatively low, therefore, banks (and subsequently companies and individuals) do not have to be concerned about the consequences of the crisis in the form of lower prices of mortgaged assets. (Čevorova, Drotar, Spalovský, \& Straňák, 2010)

In terms of the quality of assets of Czech banking sector, including the building savings societies, bank balance sheets for the period of 2002 through 2012 were in relatively good shape, also due to rigorous supervision on the part of the CNB. The quality of loan portfolios, which is the most significant factor in respect of the nature of the domestic banking sector, is illustrated in Figure 4. Until 2008, nonperforming (defaulted) loans were continuously declining. The worsening quality of loans, triggered in 2008, mainly due to macroeconomic consequences of the global financial crisis, came to a halt in 2011. In the course of 2012, the indicator value declined slightly. In spite of this, however, it is safe to say that the share of nonperforming loans 
is roughly at 50-percent compared to the situation in 2002 (MF, 2013a). Therefore, it can be concluded that both loan providers and loan recipients came through in this regard. Worse results of the indicator for the construction industry reflect the very strong restrictive state policy after 2010, aiming at reducing public debt. At the time, the support provided to mortgage loans and buildings savings is significantly reduced as well (see Table 1).

Table 1

Direct and Indirect Housing Support in the Czech Republic (CZK bn.)

\begin{tabular}{lccccccccccc}
\hline Indicator & 2002 & 2003 & 2004 & 2005 & 2006 & 2007 & 2008 & 2009 & 2010 & 2011 & 2012 \\
\hline $\begin{array}{l}\text { State support to mortgage } \\
\text { loans }\end{array}$ & 11.6 & 13.26 & 15.34 & 16.9 & 15.77 & 14.98 & 14.22 & 13.26 & 11.74 & 10.73 & 5.29 \\
$\begin{array}{l}\text { Building savings support } \\
\text { contribution }\end{array}$ & 0.46 & 0.50 & 0.47 & 0.34 & 0.17 & 0.08 & 0.02 & 0.04 & 0.02 & 0.02 & 0.02 \\
\hline
\end{tabular}

Note. Soure: MF 2013b, own elaboration.

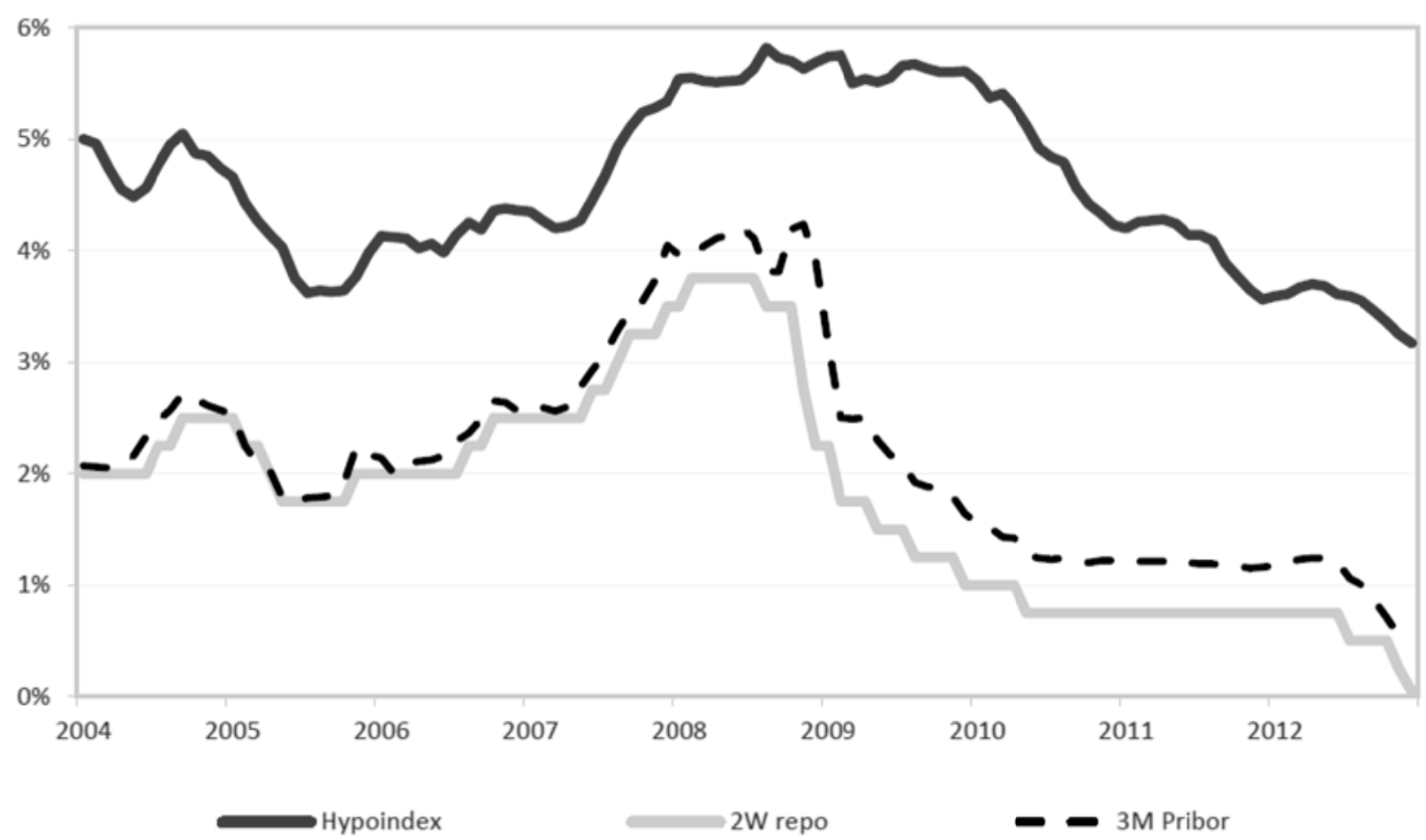

Figure 3. Development of selected interest rates. Source: Fincentrum, CNB.

In addition to the main causes of the economic crisis, as described above, there are contradicting opinions on whether the overly accommodating tax support of the mortgage loan market contributed to the financial crisis or not. From this perspective, the US tax system did not differ from other forms of housing support prevailing in other countries. However, it must be noted that even such support contributes to the expansion of loans, particularly of mortgage loans. Taxes also affect the decision on whether it is more beneficial to own or rent one's housing. Relatively low real-estate/real-estate transfer taxes mainly promote home ownership. However, tax policy was not the key impulse of speculative bubbles either in the U.S., Spain, or Ireland. Nevertheless, the degree of this effect is difficult to quantify. Many countries reacted to the crisis by adopting significant tax measures as part of more comprehensive fiscal stimulation packages. In general, the measures 
consisted in lowering existing taxes, although some countries, e.g., Latvia, Lithuania, or Ireland, increased them for budgetary reasons. Most measures targeted lower taxation of labor, particularly by reducing personal income tax rates or broadening income tax brackets in case of progressive taxation. Other part of tax measures focused on lowering corporate income taxes, either by reducing tax rate or tax base. However, no country reduced VAT rates in order to increase consumption (Hemmelgarn \& Nicodeme, 2010).

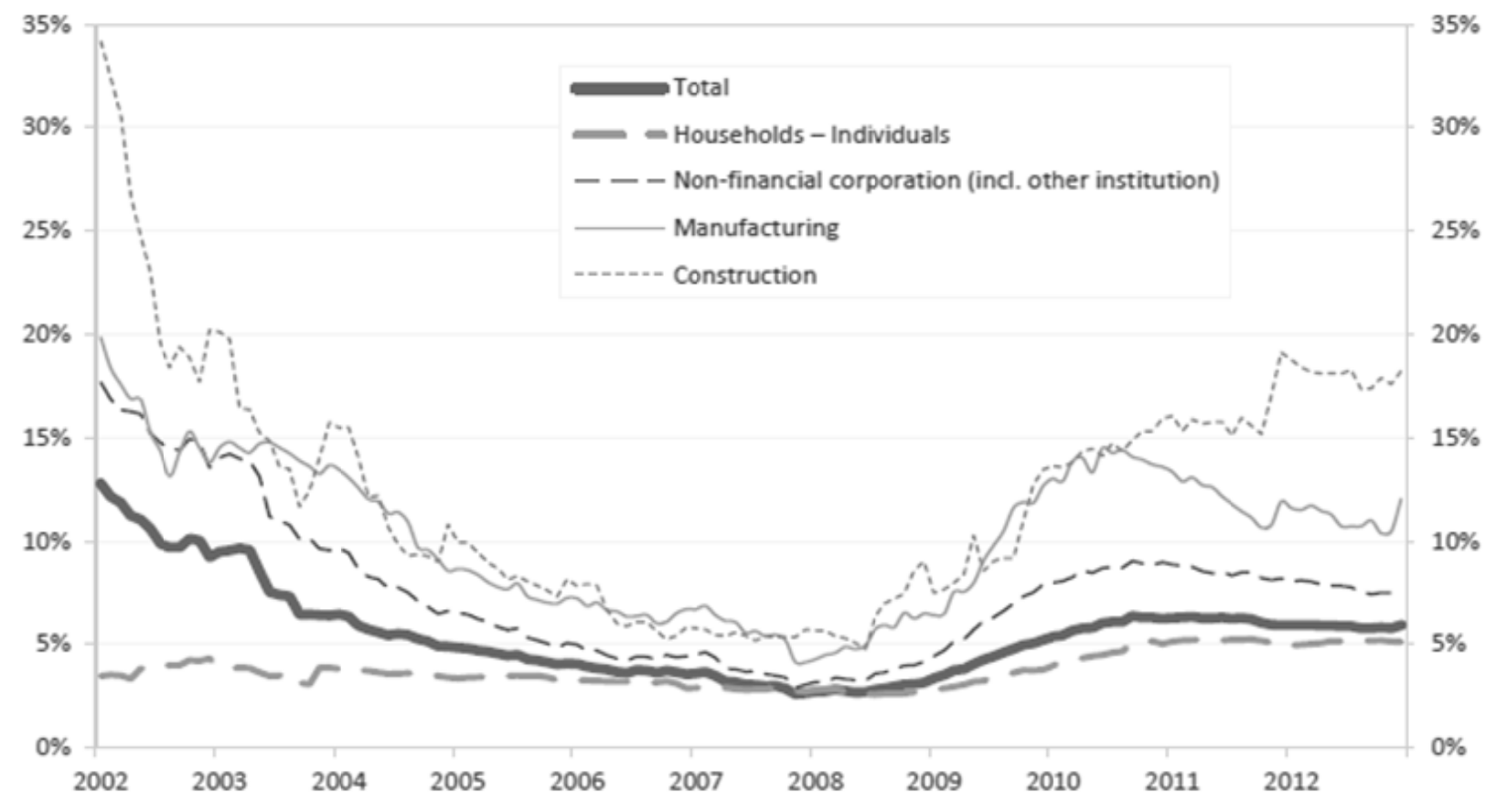

Figure 4. Distribution of nonperforming loans. Source: CNB-ARAD.

This is also in accordance with the content and conclusion of the IMF study "Debt Bias and Other Distortions: Crisis-Related Issues in Tax Policy" of 2009. According to the study, tax policy of many countries contributed to the vulnerability of the financial system, whereas existing tax systems stimulate companies to finance their activities through loans. These results in proposals for structural tax reforms. The IMF study warns about the emergence of tax distortions due to overly generous tax incentives associated with debt financing, where such incentives may lead to preferred use of debt to equity in case of companies. The distortions, induced by tax policy, as well as associated risks represent a major factor for each country's financial stability, even though they are not the predominant cause of the crisis. However, they very likely contributed to key errors that became apparent in the course of the financial crisis. This is why it was recommended to impose a more neutral tax system, with a minimum of exemptions or tax allowances. Moreover, it is necessary to align conditions for loan vs. equity financing. This may be done in one of the following ways: either by eliminating tax deductibles relating to interest or tightening up the conditions for their application, or by allowing tax benefits.

Even though the support of home ownership did not cause any of the above described problems, the Czech Republic has been reforming its tax system as part of its restrictive fiscal policy in line with the above mentioned recommendations, i.e., gradually increases taxation of consumption in favor of income taxation, while continuously eliminating various exemptions, particularly in the Income Tax Act. Consequently, the tax 
support of housing has been declining, for example, the exemption of interest accrued on building savings deposits was discontinued as of 2011. Increasing VAT consumption tax translated into lower consumption, particularly of households but also of the government, resulting further decline of GDP in 2012 and 2013. The objective, i.e., the public debt reduction, has not been met.

In October 2010, the European Commission started to consider the introduction of a new tax on financial transactions. It only applies to transactions relating to financial instruments. However, it will not affect mortgage loans. One of the reasons for such new tax is the fact that the financial sector should bear a fair share of costs incurred due to the crisis, after receiving very significant financial support from many governments as from the onset of the financial crisis. The tax on financial transactions should thus become an instrument of the financial market stabilization and improvement of their operation, because it would increase transaction costs, thereby reducing potential for highly speculative transactions. In addition to this, the tax would also increase tax revenue, without invoking economic decline. Theoretical discussions regarding the potential effect of financial transaction taxes are not unambiguous. Opponents of the new tax claim that it would lead to higher transaction costs, which would in turn limit the market liquidity and consequently the market effectiveness as well (Hemmelgarn \& Nicodeme, 2010).

Overall, 14 of the $28 \mathrm{EU}$ member states agree with the introduction of the financial transaction tax. The previous Czech government rejected the tax at the beginning of 2013, stating that banks in the Czech Republic did not contribute to the financial crisis and, on the contrary, acted cautiously in respect of the provision of loans, including mortgage loans. However, there are other views as well:

We should not block the introduction of the financial transaction tax, which is currently sought by the European Commission and the European Parliament as the EU's own tax revenue.

Tax is expected to restrain speculative financial transactions and is also in accordance with the views of many nongovernment organizations that promote the financial sector taxation due to its high profitability or exceptional solvency, as appropriate. (Vostatek, 2012)

In this regard, it is also possible to add that the support of the banking sector, including building savings societies, still exists from the expenditure of the Czech state budget (see Table 1), and this increases their liquidity and consequently their profits. The provided funds should flow back to the state budget in the form of taxes. It would be a small contribution to the continuing effort of the government aimed at consolidating the public budgets.

\section{Conclusions and Recommendation}

As part of their housing policy, many countries try to make housing more accessible and support residential housing development. In this area, state support targets mainly individuals. It is safe to state that these measures were nearing more developed countries; however, the housing support was suppressed after 2008, which is associated not only with the effort to simplify the tax system in the Czech Republic, but also with the fiscal consolidation of public finance. Moreover, the reasons of the mortgage crisis in the US, with severe implications for the global economy, served as a warning.

In the 1990s, the direct housing support in the form of subsidies from the state budget expenditure dominated in the Czech Republic; in connection with declining interest rates, particularly the mortgage loans that were associated with subsidies of mortgage loan interest rates in excess of a specific level set down by a Government Decree have been gradually suppressed as of 2004. In the first decade of the new millennium, 
mainly tax allowances associated with possible tax deductions of interest paid on mortgage loans/building savings loans from a tax base contributed to the support of the Czech housing market. It is safe to say that this legislative regulation, existing in the Income Tax Act since 1998, significantly increased the household indebtedness, namely, in the form of housing loans. This indebtedness has remained at a safe level in terms of international comparison. Of the two supported loan types, mortgage loans have been slightly growing, while the building savings loans have been stagnating in the past three years, which also relates (among others) to the declining state support.

In spite of the aforementioned developments, the Czech Republic reports one of the lowest household indebtedness of all EU member states. Development on the mortgage market has recently been associated with two aspects; the first aspect-the currently all-time low interest rates derived from the CNB interest rate - contributes to growth of the housing loan market. On the other hand, the second factor-measures implemented in connection with the public finance consolidation - has an opposite effect. In addition to the gradual disappearance of the direct housing support in the form of subsidies funded by the state budget expenditure, the tax measures are subject to changes as well. Many various exemptions have been eliminated. As of 2008, indirect taxation has been significantly promoted at the expense of direct taxation. This factor also reduced the housing support.

However, it was necessary to implement the aforementioned measures in connection with the global economic recession caused by the financial crisis. The IMF and the EU concluded that the mortgage crisis was partially caused by the overly generous tax support of loans, although it was not the key factor. However, it holds true for all economies affected by the recession that they must set up their tax system as neutral, if they wish to achieve financial stability. This is mainly the case of countries with high level of indebtedness. Even though the Czech Republic is the seventh least indebted country among the EU member states, with relatively low household indebtedness, problems with the repayment of household loans are starting to increase. For these reasons, but particularly due to various efforts aimed at reducing mandatory expenditure and thereby the budget deficit, the state support in the area of housing has been gradually declining since 2008 .

It is safe to state that the measures relating to the housing support in the Czech Republic have been sufficient since 1990s, because they contributed to the country's economic growth, particularly after 1998 . The growth continued until 2009, when it was affected by the global economic crisis. Subsequent measures, associated with suppression of direct housing support, were mainly related with efforts of reducing public debt. It would also be beneficial to introduce a sector tax or financial transaction tax, for example, even though banks in the Czech Republic have always acted cautiously in providing housing loans. There is a possibility that the tax may become one of the sources of funding for the EU budget and, consequently, it will be necessary to implement the tax within the Czech tax system.

\section{References}

Čevorova, N., Drotar, M., Spalovský, M., \& Straňák, P. (2010). Řešení hospodářské krize—dopady na podnikatelský sektor (Resolving the economic crisis-Implications for the business sector). Acta Oeconomica Pragensia, 18(3), 63-88.

Delloite. (2010). The role of the government in EU real estate markets. Retrieved from http://www.deloitte.com/view/en_ro/ro/6ef7a05a61cd7210VgnVCM200000bb42f00aRCRD.htm

Hemmelgarn, T., \& Nicodeme, G. (2010). The 2008 financial crisis and taxation policy. Taxation Papers, No. 20, Luxembourg: Office for Official Publications of the European Communities.

IMF. (2009). Debt bias and other distortions: Crisis-related issues in tax policy. Retrieved from 
http://www.imf.org/external/np/pp/eng/2009/061209.pdf

Klíma, J. (2010). Podpora bytové výstavby v zemích Evropské unie (Support of residential development in EU member states). Prague. Obec a finance 4/2010. Retrieved from http://www.dvs.cz/clanek.asp?id=6460583

MF. (2013a). Zpráva o vývoji finančního trhu v roce 2012 (Report on the financial market development in 2012). Prague: Ministry of Finance of the Czech Republic.

MF. (2013b). Návrh státního závěrečného účtu České republiky za rok 2012 (Draft State Annual Accounts of the Czech Republic for 2012). Prague: Ministry of Finance of the Czech Republic.

Vostatek, J. (2012). Zdanění a dotování finančního sektoru (Taxing and subsidizing the financial sector in Helisek). Prague: Vysoká škola finanční a správní.

Wolswijk, G. (2005). On some fiscal effects on mortgage debt growth in the EU. Working Paper Series No. 526.

Zemánek, J. (2008). Hypoteční krize v USA. Př́činy, průběh, následky (Mortgage crisis in the US: Causes, course, and consequences). Retrieved from http://www.euroekonom.cz/analyzy-clanky.php?type=jz-usa-hypoteky3 